\title{
Game method to increase students' motivation to engage in elective disciplines in physical culture and sports
}

\author{
Inna N. Ovsyannikova ${ }^{\mathrm{ABDE}}$, Konstantin G. Tomilin ${ }^{\mathrm{ABCDE}}$, Yulia A. Tumasyan ${ }^{\mathrm{BDE}}$, Yulia A. Vasilkovskaya ${ }^{\mathrm{BDE}}$,
} Lyudmila V. Malygina ${ }^{\mathrm{BDE}}$

Sochi State University, Sochi, Russia

Authors' Contribution: A - Study design; B - Data collection; C - Statistical analysis; D - Manuscript Preparation; E - Fund Collection

\begin{abstract}
Background A serious problem when using the play method in training sessions is the regulation of physical activity. and Study Aim For students with poor health, high emotionality of classes and intense rivalry between teams can lead to undesirable consequences for health. Purpose of the research: assessment of the effectiveness of the game method to increase the motivation of students to engage in elective disciplines in physical culture and sports.

Material and The study involved first-year students of Sochi State University (Russia) ( $n=25)$, with different experience Methods in physical culture and sports. The training sessions ( 6 hours a week) lasted two academic semesters ( 9 months) and included outdoor games. A daily «scan» of the current functional state of the students was carried out by heart rate, express scales («Emotional excitement and physical fatigue» and «Well-beingActivity-Mood»). The indicators of general physical fitness of students were registered. The results were analyzed in Microsoft Excel 2010 computer programs. The significance of the change was determined by the Wilcoxon test using the significance level $p \leq 0.05$.

Results The use of a large number of outdoor games and relay games in the classroom contributed to the increase of students' motivation to engage in elective disciplines in physical culture and sports. Which led to almost $100 \%$ of class attendance and improved agility, flexibility and endurance indicators among students $(p<0.05)$. There was a decrease in the indicator in the test «pulling up on a high bar» among young men $(p<0.05)$.

Conclusions: The study showed new prospects for using the game method in the classroom not only with homogeneous groups of students, but also with students with different levels of physical fitness and health. By manipulating the composition of the playing teams, each of the participants was regularly provided with strong and varied emotions. That increased the interest in students attending classes. The use of the «Express-control» system for the current functional state of the trainees (primarily for students with weakened health) ensured prompt correction of the intensity of physical activity.

Keywords: $\quad$ students, outdoor games, relay games, class classification, express control, functional state, physical fitness.
\end{abstract}

\section{Introduction}

A person in the process of his life goes through certain stages of development [1], on the overcoming of which his further well-being and health largely depends. The most critical phase is the end of adolescence, which coincides with the admission of a young person to a higher education institution. At this stage, students become independent and responsible for their own lives, especially if they are far from the parental home [2].

The World Health Organization (WHO) has repeatedly emphasized the need for sufficient physical activity for the health of today's youth $[3,4]$. Its certain level contributes to physiological and psychological resistance to stress [5] and mental health [6, 7].

At present, there is a decrease in the attention of society to the physical education of young people, both in Europe [8-10] and America [11-13], and in Russia $[14,15]$. Experts point to the need to increase the level of physical condition and motor activity of students by increasing the number of physical culture lessons [16] with a weekly motor regime exceeding 4-6 hours [17-20].

(c) Inna N. Ovsyannikova, Konstantin G. Tomilin, Yulia A. Tumasyan, Yulia A. Vasilkovskaya, Lyudmila V. Malygina, 2021

doi:10.15561/20755279.2021.0308
It is advisable to stimulate physical activity by increasing the motivation of students to independent motor activity [21-23].

A significant positive factor can be the use of modern pedagogical technologies and new types of physical activity in the activities of the university. The implementation will allow attracting students to regular physical education and sports classes. To form in them a value attitude towards a healthy lifestyle [24]. Adaptation of high technologies of sports training to the needs and conditions of physical education of young people is perspective. And also the use of the «activity approach» in the process of teaching and upbringing, with a change in the relationship between the participants in the pedagogical process. The authoritarian pedagogy should be replaced by the pedagogy of cooperation [25].

Outdoor games are an effective means of increasing youth motivation for physical activity. Scientific researches of Russian scientists reveal the peculiarities of the use of outdoor games in folk traditions [26-31], in classes with schoolchildren and students [32-34] and sports training [35-37]. The authors note that the use of the game method allows you to diversify the relationship 
between those involved (colleagues and rivals), and the application of the rules contributes to the development of moral and ethical standards of behavior. The unpredictable development of the game requires the participants to show initiative and creativity in order to achieve success.

For students of the academic group with disabilities, you can choose feasible roles in outdoor games, which allows you to include in the classroom all, without exception, those present [38]. During training sessions, students are taught to change the content of outdoor games for their further use in various conditions of the resort (on the water, on a sandy beach, etc.) [39, 40].

The use of informal sports and game-oriented classes will intensify physical activity in comparison with traditional forms of physical culture in universities, both for students with good physical training, as well as for people with weakened health [41-43]. However, there is a concern that coordinated and physically prepared students will dominate the game-oriented classes, leading to the passivity of other participants in the class. Forming in them an inferiority complex and a decrease in interest in classes.

A serious problem when playing games can be the lack of rationing of physical activity. That, for students with poor health, with high emotionality of classes, and acute rivalry between teams, can lead to undesirable consequences.

It should be noted that students studying in the Sochi region are in a special natural and climatic zone of Russia and in a year-round entertainment and recreational atmosphere. The mastery by students of a large number of outdoor games provides an opportunity to use this experience during outdoor activities with relatives and friends. And also in his future career, applying this experience at corporate events.

At the same time, the population of the Sochi region is historically different in mentality, traditions, ways of earning and resting from the inhabitants of other regions of the South of Russia. This is due to the atmosphere of a constant holiday and a large number of entertainment events for the guests of the resort. Sochi youth, accustomed to this atmosphere, are less interested in physical culture and sports, compared to youth in other regions of Russia. What determines the relevance of our research.

Purpose of the research: assessment of the effectiveness of the game method in increasing the motivation of students to engage in elective disciplines in physical culture and sports.

\section{Materials and Methods}

\section{Participants.}

The research involved first-year students of Sochi State University $(\mathrm{n}=25)$, studying in the profile «Service of engineering systems of hotel and tourist complexes and sports facilities» ( 10 boys and 15 girls). The formation of the contingent of the subjects took place in a random way: the students were of the same training group, with different experience in physical culture and sports. Among them there are two former highly qualified athletes who have been engaged in rhythmic gymnastics for 7-10 years, 4 people - young men who are fond of football and strength training equipment. And also 4 students who did not go in for physical education at school for health reasons. The approval of Sochi State University (Russia) Ethics Committee was obtained for the study to be implemented. All procedures conducted were accordance in with the Declaration of Helsinki.

\section{Research Design.}

The main part was held with more than 7 dozen outdoor games taken from collections of Russian and Western European folk outdoor games and relay games. Preference was given to games that could be used in the conditions of the water resort [40, 44, 45]. For the convenience of teachers, they were presented in the classification of play-oriented classes (Table 1).

In the classroom, the composition of the playing teams was manipulated so that the students' activities were conducted in different conditions, allowing everyone to feel strong emotions, both from victories and from defeats.

The final part (exercises for strength, flexibility; the simplest exercises from yoga and qigong), with a summary of the lesson, a survey of well-being and a task for self-fulfillment. Duration of classes per week -6 academic hours.

Particular attention was paid to monitoring the current functional state of the trainees. This is due to the complex relationship between heart rate and subjective perception of load in play [45]. Therefore, we made an attempt to use the technologies of current control of members of the USSR / Russian national teams [46] and tourists at water resorts [47].

Such diagnostics, if possible, should be carried out repeatedly during the lesson, and monitor the condition of the trainees when they perform physical activities. The methodological principle «Obtaining the maximum of information with a minimum of recorded indicators» is used, and the introduction of a multi-level control system:

Level 1 - visual methods of monitoring the state and behavior of a student;

Level 2 - a survey of those in poor health (if necessary) about their health, degree of physical fatigue, mood, etc.;

Level 3 - diagnostics of the current functional state of the body by registering the pulse (resting heart rate, etc.);

Level 4 - diagnostics (if necessary) of individual systems of the human body using the simplest, hardwarebased express methods (heart rate dynamics after exercise, blood pressure measurement, etc.);

Level 5 - in some cases, examination of a student using modern instrumental techniques in a sports dispensary, polyclinic or diagnostic center [46, 47].

In our classes, we used daily express scales of visual control of the level of emotional arousal and the degree of physical fatigue of the trainees (Table 2).

If necessary, the subjective feelings of students about their health were specified - «Express-health-activitymood» (Table 3$)$. 
Table 1. Classification of game activities of students

\begin{tabular}{|c|c|c|c|c|c|c|c|}
\hline Signs & \multicolumn{7}{|l|}{ Groupings } \\
\hline By the number & Singles (individual & \multicolumn{3}{|c|}{ Small group (2-4 people) } & \multicolumn{3}{|c|}{ Mass (group, team) } \\
\hline $\begin{array}{l}\text { The nature of } \\
\text { motor activity }\end{array}$ & \multicolumn{2}{|c|}{$\begin{array}{l}\text { Low activity (in motor actions } \\
\text { actively for a relatively long time, } \\
\text { one or two students alternately } \\
\text { participate; those involved move } \\
\text { freely or perform small calm } \\
\text { movements) }\end{array}$} & \multicolumn{3}{|c|}{$\begin{array}{l}\text { Average activity (active } \\
\text { participation of all students } \\
\text { in motor actions; active } \\
\text { participation of individual } \\
\text { students or small groups of } \\
\text { students in motor actions) }\end{array}$} & \multicolumn{2}{|c|}{$\begin{array}{l}\text { Great activity (active } \\
\text { and simultaneous } \\
\text { participation of all } \\
\text { students in motor } \\
\text { actions; active and } \\
\text { alternating participation } \\
\text { of groups engaged in } \\
\text { motor actions) }\end{array}$} \\
\hline Game content & \multicolumn{3}{|c|}{$\begin{array}{l}\text { Simple (easily surmountable obstacles, } \\
\text { elementary student interactions) }\end{array}$} & \multicolumn{4}{|c|}{$\begin{array}{l}\text { Complex (insurmountable obstacles, } \\
\text { complex interactions of students) }\end{array}$} \\
\hline Typical actions & Freestyle & \multicolumn{2}{|l|}{ Rhythmic } & \multicolumn{3}{|c|}{ Role-playing } & Creative \\
\hline $\begin{array}{l}\text { Manifestation } \\
\text { of physical } \\
\text { qualities }\end{array}$ & $\begin{array}{l}\text { Agility (quick } \\
\text { transition from } \\
\text { one action } \\
\text { to another; } \\
\text { combination of } \\
\text { one's actions with } \\
\text { the actions of } \\
\text { other students; } \\
\text { ability to focus on } \\
\text { several actions) }\end{array}$ & $\begin{array}{l}\text { Quickness } \\
\text { (timely motor } \\
\text { responses to } \\
\text { visual, tactile, } \\
\text { sound signals; } \\
\text { overcoming } \\
\text { short distance } \\
\text { in the shortest } \\
\text { possible time, } \\
\text { in changing } \\
\text { conditions) }\end{array}$ & $\begin{array}{l}\text { St } \\
\text { te } \\
\text { te } \\
\text { dy } \\
\text { st }\end{array}$ & $\begin{array}{l}\text { ngth (short- } \\
\text { muscle } \\
\text { ions of a } \\
\text { amic and } \\
\text { c nature) }\end{array}$ & \multicolumn{2}{|c|}{$\begin{array}{l}\text { Endurance } \\
\text { (repeated } \\
\text { repetitions } \\
\text { of active, } \\
\text { vigorously } \\
\text { performed } \\
\text { actions } \\
\text { associated } \\
\text { with } \\
\text { continuous } \\
\text { intense } \\
\text { movements, } \\
\text { in which } \\
\text { active actions } \\
\text { alternate } \\
\text { with short } \\
\text { rest pauses, } \\
\text { transitions } \\
\text { from one type } \\
\text { of movement } \\
\text { to another) }\end{array}$} & $\begin{array}{l}\text { Flexibility } \\
\text { (motor actions } \\
\text { with a large } \\
\text { amplitude; } \\
\text { movements } \\
\text { to music in } \\
\text { combination } \\
\text { with dance } \\
\text { steps, using } \\
\text { objects that } \\
\text { help to acquire a } \\
\text { sense of rhythm, } \\
\text { plasticity of } \\
\text { movements, } \\
\text { the ability to } \\
\text { feel the speed } \\
\text { and duration } \\
\text { of movements, } \\
\text { regulate muscle } \\
\text { efforts; climbing } \\
\text { and climbing) }\end{array}$ \\
\hline Entertainment & \multicolumn{3}{|c|}{$\begin{array}{l}\text { Attractions (effectively demonstrated } \\
\text { motor actions that require composure and } \\
\text { endurance) }\end{array}$} & \multicolumn{3}{|c|}{$\begin{array}{l}\text { Competitions (identifying } \\
\text { the best among the } \\
\text { participants in the game) }\end{array}$} & $\begin{array}{l}\text { ghts (wrestling } \\
\text { two or more } \\
\text { ponents) }\end{array}$ \\
\hline
\end{tabular}

Table 2. Scale-questionnaire «Express-FAM» to clarify the current functional state of those involved

\begin{tabular}{|c|c|c|c|}
\hline $\begin{array}{l}\text { Level } \\
\text { (points) }\end{array}$ & FEELING & ACTIVITY & MOOD \\
\hline 10 & \multirow{4}{*}{$\begin{array}{l}\text { Best for many years } \\
\text { Excellent } \\
\text { Very good } \\
\text { Good, nothing does not } \\
\text { hurt }\end{array}$} & I am burning with desire move & The most joyful moment in my life \\
\hline 9 & & Very large desire to move & Everything is fine everything works out \\
\hline 8 & & I really want train & Great, everything goes fortunately \\
\hline 7 & & I want to train & Good \\
\hline 6 & Good & I wanted a little to practice & Above average \\
\hline 5 & Daily, normal & Indifferent & Normal, normal \\
\hline 4 & Not very good & Probably no need to train today & Slightly spoiled \\
\hline 3 & Bad (malaise) & I do not want train & Bad \\
\hline 2 & Very bad & I don't want to even move & Very bad continuous failures \\
\hline 1 & Disgusting (is ill) & $\begin{array}{l}\text { Extremely negative attitude } \\
\text { towards training }\end{array}$ & Disgusting, major failures \\
\hline 0 & Terribly sick, hard to move & $\begin{array}{l}\text { One thought of training is } \\
\text { disgusting }\end{array}$ & $\begin{array}{l}\text { Catastrophic position, shocked by what } \\
\text { has fallen on me }\end{array}$ \\
\hline
\end{tabular}


Under unfavorable conditions of students (in the tables highlighted in yellow and red fields, according to the type of «Traffic light»), the physical load decreased. Heart rate measurements (with devices «Xiaomi Mi 4c», Yingu Mansion, China) during the training allowed to control and quickly change the intensity of physical activity. The methods of direct and indirect regulation of the intensity of motor activity were used.

For the training sessions, teachers selected outdoor games and relay games with the maximum number of participants [48]. Guided by the recommendations that play-based learning «may in fact be the dominant technology of education». And by manipulating the composition of the playing teams, so that each of the students regularly has the opportunity to openly show emotions, both from victories and from defeats.

Pedagogical observation made it possible to identify students who showed initiative, providing a variety of exercises, high density and intensity of classes.

Changes in the indicators of general physical fitness of students were recorded (Table 4).

Statistical Analysis.

The indicators were analyzed in Microsoft Excel 2010 computer programs: arithmetic mean $(\bar{X})$, standard deviation $(\sigma)$. The reliability of changes in the results was determined by the Wilcoxon test, using the significance level $\mathrm{p} \leq 0.05$.

\section{Results}

The first survey in September 2018 (fourth column of Table 4) showed satisfactory (on average for the group) physical fitness of Sochi students. For example, this table (third column) shows the requirements for the «Bronze Sign» of the «Ready for Labor and Defense» (TRP) complex adopted in Russia. However, some young people were completely unaccustomed at school to intense physical activity in physical education classes.

For 9 months of playing activity, an improvement in the indices of dexterity, flexibility and endurance of the trainees was revealed $(\mathrm{p}<0.05)$. The indicator of «pulling up on a high bar» in boys decreased $(\mathrm{p}<0.05)$ (Table 4 , Figure 1).

Pedagogical observation allowed the identification of students who showed initiative, providing a variety of exercises, high density and intensity of classes and used by such students as teaching assistants.

Table 3. Visual control of the level of emotional arousal and the degree of physical fatigue involved

\section{Level (points) \\ Visual symptoms of emotional arousal}

\section{Visual symptoms of physical fatigue}

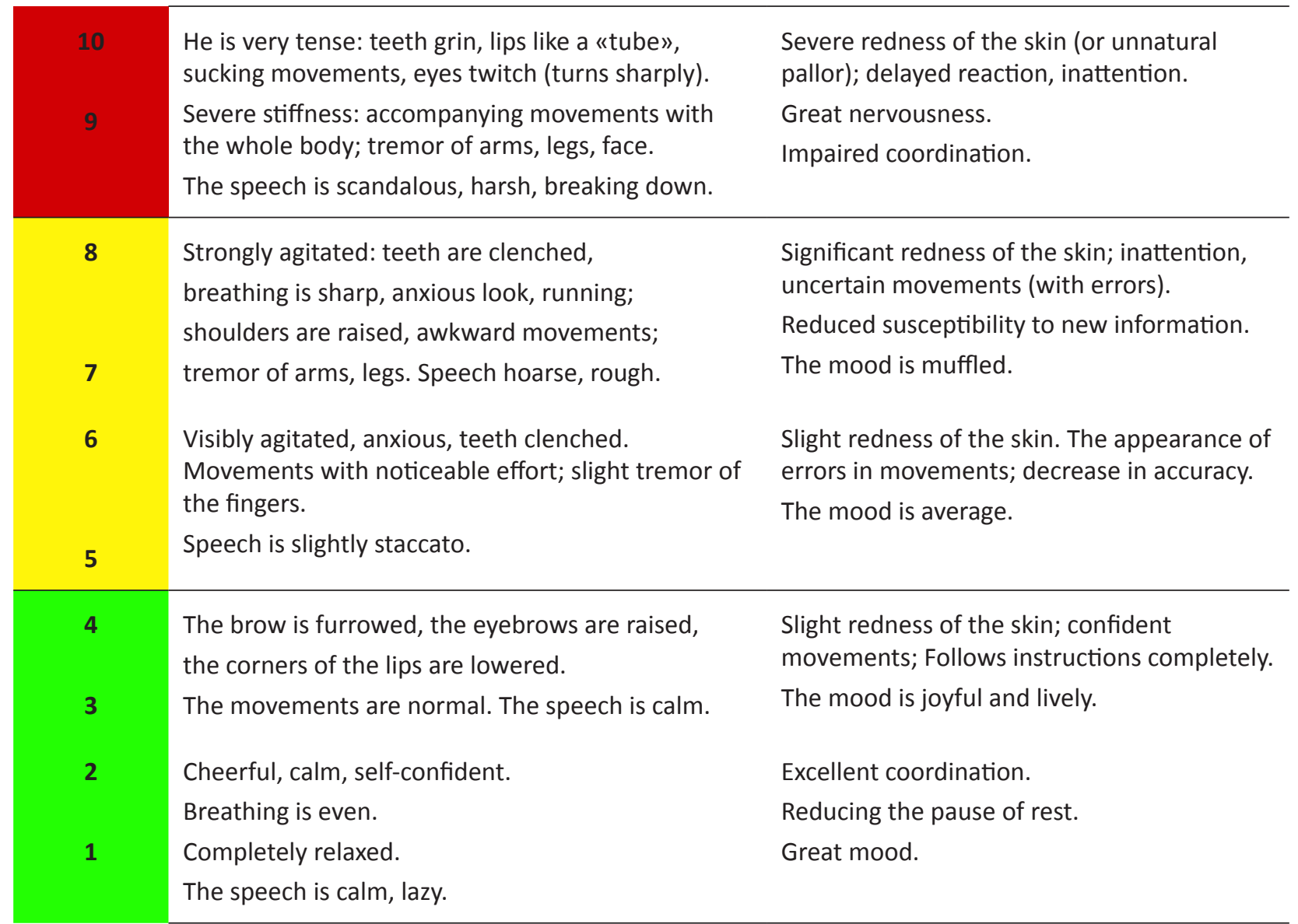


Table 4. Change of indicators of general physical fitness of students going in for sports and outdoor games

\begin{tabular}{|c|c|c|c|c|c|c|}
\hline № & Indicators & Contingent & $\begin{array}{l}\text { TRP } \\
\text { requirements } \\
\text { for the } \\
\text { «Bronze Sign» }\end{array}$ & $\begin{array}{l}\text { September } \\
2018(\bar{X} \pm \sigma)\end{array}$ & $\begin{array}{l}\text { May } 2019 \\
(\bar{X} \pm \sigma)\end{array}$ & p \\
\hline 1 & 2 & 3 & 4 & 5 & 6 & 7 \\
\hline 1 & Shuttle run $3 \times 10$ m (s) & $\begin{array}{l}\text { Boys } \\
\text { Girls }\end{array}$ & $\begin{array}{l}8.0 \\
9.0\end{array}$ & $\begin{array}{l}7.9 \pm 0.4 \\
8.6 \pm 0.5\end{array}$ & $\begin{array}{l}7.2 \pm 0.4 \\
7.9 \pm 0.5\end{array}$ & $\begin{array}{l}p<0.05 \\
p<0.05\end{array}$ \\
\hline 2 & $\begin{array}{l}\text { Cooper's test (12 min run) (m) } \\
\text { Lean forward from a standing }\end{array}$ & $\begin{array}{l}\text { Boys } \\
\text { Girls } \\
\text { Boys }\end{array}$ & +6.0 & $\begin{array}{l}2000.0 \pm 429.2 \\
1887.5 \pm 196.7 \\
+7.5 \pm 5.3\end{array}$ & $\begin{array}{l}2141.3 \pm 346.4 \\
1992.1 \pm 204.0 \\
+8.9 \pm 6.3\end{array}$ & $\begin{array}{l}p<0.05 \\
p<0.05 \\
p<0.05\end{array}$ \\
\hline 3 & $\begin{array}{l}\text { position on a gymnastic bench } \\
(\mathrm{cm})\end{array}$ & Girls & +8.0 & $+18.2 \pm 7.8$ & $+19.5 \pm 6.2$ & $p<0.05$ \\
\hline 4 & Standing long jump (cm) & $\begin{array}{l}\text { Boys } \\
\text { Girls }\end{array}$ & $\begin{array}{l}210.0 \\
170.0\end{array}$ & $\begin{array}{l}203.0 \pm 22.9 \\
159.1 \pm 20.4\end{array}$ & $\begin{array}{l}199.6 \pm 50.0 \\
161.0 \pm 22.8\end{array}$ & $\begin{array}{l}p>0.05 \\
p>0.05\end{array}$ \\
\hline 5 & $\begin{array}{l}\text { Raising the body from a prone } \\
\text { position, for } 1 \text { min (times) }\end{array}$ & $\begin{array}{l}\text { Boys } \\
\text { Girls }\end{array}$ & $\begin{array}{l}33.0 \\
32.0\end{array}$ & $\begin{array}{l}51.6 \pm 3.7 \\
44.6 \pm 6.7\end{array}$ & $\begin{array}{l}50.1 \pm 6.9 \\
44.3 \pm 7.2\end{array}$ & $\begin{array}{l}p>0.05 \\
p>0.05\end{array}$ \\
\hline 6 & $\begin{array}{l}\text { Pulling up on a high bar, } \\
\text { (times) } \\
\text { Flexion-extension of the arms, } \\
\text { in the lying position, (times) }\end{array}$ & Girls & 10.0 & $13.6 \pm 7.8$ & $12.9 \pm 5.4$ & $p>0.05$ \\
\hline
\end{tabular}

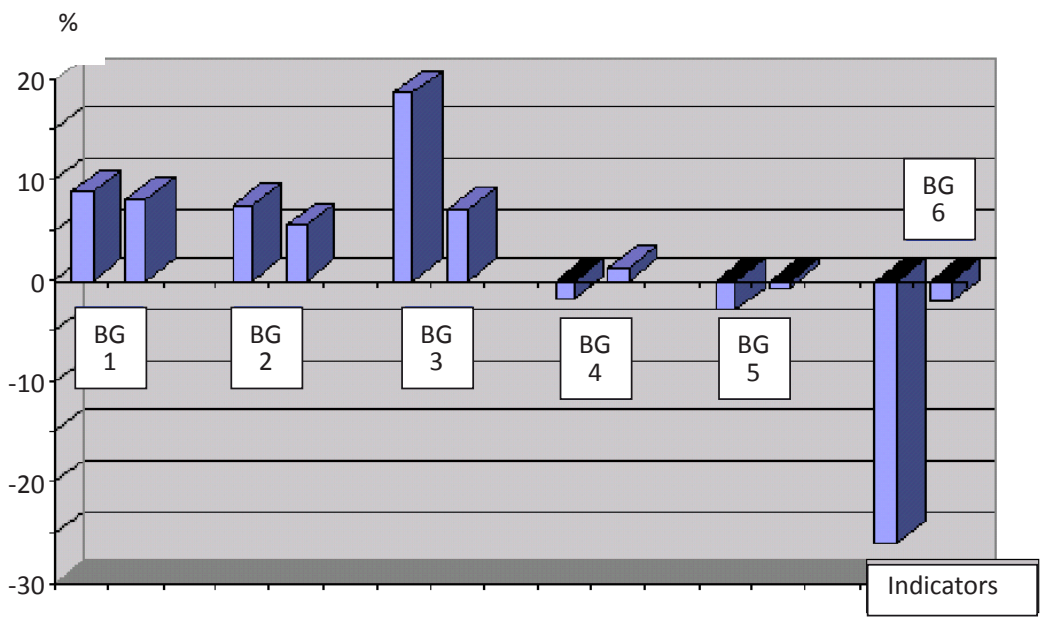

Figure 1. Changes in the indicators of physical readiness of students involved in sports and outdoor games: 1 - shuttle run $3 \times 10 \mathrm{~m} ; 2$ - Cooper's test (12 min run); 3 - lean forward from a standing position on a gymnastic bench; $4-$ long jump from a place; 5 - raising the trunk from a prone position, in 1 min; 6 - pulling up on a high bar (boys), flexionextension of the arms, in the lying position (girls).

\section{Discussion}

Pedagogical observation and survey showed a high motivation for playing activities, which fully coincides with the results of other researchers [49-52].

The wide use in the classroom of a varied combination of outdoor games and relay games, taking into account the interests of students, ensured an increase in attendance up to $100 \%$. Students who were exempted from practical physical education classes at school (for health reasons) began to attend systematically. A positive emotional attitude and high physical activity required monitoring the state of the trainees and prompt correction of the intensity of physical activity. The formation of students' social confidence among their peers and in communication with teachers was carried out, as noted in the studies of other authors [28]; the development of the legal foundations of gaming activities took place [30]. The skills and abilities of playing games were practiced, which they may need even in later family life in contact with children [32, 34].

Gaming-oriented classes contributed to the creativity of the students, which coincides with the data of other researchers $[35,37]$ and the change in the relationship between the participants in the pedagogical process in the systems «teacher-student» and «student-student». There was a change from authoritarian pedagogy to pedagogy of cooperation. Introducing students to traditions, conducting folk outdoor games [26].

At the beginning of the pedagogical experiment, an increased desire of young men to engage in the development of strength, to the detriment of other physical qualities, was noted. For girls - the development of flexibility. But both of them gladly took part in outdoor games, including students who had not previously been involved in physical culture. That required increased 
attention of teachers to this group and regular use of the express control system of their current functional state.

The studies have proved the high efficiency of the game method in increasing the motivation of Sochi students to engage in elective disciplines in physical culture and sports. That, with the manipulation of the composition of the involved teams, and in combination with the use of the «Express control» system for the current functional state of students (for the operative correction of the intensity of physical influences), provided adequate physical activity in the group, both for well-trained athletes and persons with weakened health.

The lack of modern inventory and equipment of the gym and the small amount of time allotted in the curriculum for classes in elective disciplines in physical culture and sports did not allow to achieve the desired improvement in all indicators of physical fitness in full.

\section{Conclusion}

The study showed new prospects for using the game method in the classroom not only with homogeneous groups of students, but also with people with different levels of physical fitness and health. By manipulating the composition of the playing teams, each of the participants was regularly provided with strong and varied emotions. That increased the interest in students attending classes. The use of the «Express-control» system for the current functional state of the trainees (primarily for persons with weakened health) ensured prompt correction of the intensity of physical activity.

Since long-term pedagogical observations have revealed a tendency towards a gradual decrease in the motivation of Sochi students to engage in physical culture and sports, as they move to senior courses of study (change of interests, search for a partner for family relations, employment, etc.), it would be interesting to implement long-term pedagogical observations of students of this group during their studies at the university. To assess the impact on participants in this group of quarantine measures during the coronavirus pandemic. To study the weekly physical activity, and the use of the arsenal of outdoor games learned in the classroom during picnics in nature with relatives and friends.

\section{Conflicts of interest}

The authors of the article declare that there is no conflict of interest.

\section{References}

1. Semenyuk LM. Reader on developmental psychology. [Internet]. Moscow: Institute of Practical Psychology; 1996. (In Russian). [updated 21 Jun 15; cited 2019 April 5]. Available from: http://pedlib.ru/Books/1/0374/index.shtml

2. Assaf I, Brieteh F, Tfaily M, El-Baida M, Kadry S, Balusamy B. Students university healthy lifestyle practice: quantitative analysis. Health Inf Sci Syst, 2019;7:7. https://doi.org/10.1007/s13755-019-0068-2

3. World Health Organization. Regional Office for Europe. Physical activity strategy for the WHO European Region 2016-2025. World Health Organization. Regional Office for Europe. 2016. [Updated June 25, 2019; cited April 27, 2021]. Available from: https://apps.who.int/iris/ handle/10665/329416

4. O’Donovan G, Blazevich AJ, Boreham C, Cooper AR, Crack H, Ekelund U. et al. The ABC of physical activity for health: a consensus statement from British Association of Sport and Exercise Science. Journal of Sport Science. 2010; 28 (6): 573-591 https://doi.org/10.1080/02640411003671212

5. Gerber M, Ludyga S, Mukke M, College F, Brand S, Puhse U. Low vigorous physical activity is associated with increased reactivity of the adrenal cortex to psychosocial stress in students with high perception of stress. Psychoneuroendocrinology. 2017; 80: 104-113. https://doi.org/10.1016/j.psyneuen.2017.03.004

6. Ghrouz AK, Noohu MM, Manzar MD, Spence DW, BaHammam AS, Pandi-Perumal SR. Physical activity and sleep quality in relation to the mental health of college students. Sleep and Breathing. 2019; 23(2): 627-634. https://doi.org/10.1007/s11325-019-01780-z

7. Weatherson K, Gierc M, Patte K, Qian W, Leatherdale S, Faulkner G. Complete mental health status and associations with physical activity, screen time, and sleep in youth. Mental Health and Physical Activity, 2020;19:100354. https://doi.org/10.1016/j.mhpa.2020.100354

8. Coppinger T, Milton K, Murtagh E, Harrington D, Johansen D, Seghers J, et al. Global Matrix 3.0 physical activity report card for children and youth: a comparison across Europe. Public Health. 2020;187:150-156. https://doi.org/10.1016/j.puhe.2020.07.025

9. Cristi-Montero C, Chillon P, Labayen I, Casajus JA, GonzalezGross M, Vanhelst J, et al. Cardiometabolic risk through an integrative classification combining physical activity and sedentary behavior in European adolescents: HELENA study. Journal of Sport and Health Science. 2019;8(1):55-62. https://doi.org/10.1016/j.jshs.2018.03.004

10.Uher I, Bukova A. Interrelationship between Exercise and Diseases in young people: Review study. Physical Activity Review. 2018; 6: 203-212. https://doi.org/10.16926/par.2018.06.25

11.ThomasAM,BeaudryKM, GammageKL,KlentrouP, JosseAR. Physical Activity, Sport Participation, and Perceived Barriers to Engagement in First-Year Canadian University Students. Journal of Physical Activity \& Health. 2019; 16(6): 437-446. https://doi.org/10.1123/jpah.2018-0198

12.Cardinal BJ, Sorensen SD, Cardinal MK. Historical Perspective and Current Status of the Physical Education Graduation Requirement at American 4-Year Colleges and Universities. Res Q Exerc Sport. 2012; 83(4): 503-512. https://doi.org/10.1080/02701367.2012.10599139

13.Schuch FB, Vancampfort D, Firth J, Rosenbaum S, Ward PB, Silva ES, et al. Physical Activity and Incident Depression: A Meta-Analysis of Prospective Cohort Studies. American Journal of Psychiatry. 2018;175(7):631-648. https://doi.org/10.1176/appi.ajp.2018.17111194

14.Zvyagintsev MV, Karpova TV, Sauer NG. Analysis of physical fitness of first-year students of the Novokuznetsk branchinstitute of Kemerovo State University. Scientific Notes of the University P.F. Lesgaft. 2020; 1(179): 143-147. (In Russian). https://doi.org/10.34835/issn.2308-1961.2020.143-148

15.Enchenko IV, Egorova NM. Comparative analysis of the physical activity level in europe and russian 
federation. Human Sport Medicine. 2020;20(4):103-110. https://doi.org/10.14529/hsm200412

16. Vorona V, Kylyk N, Litvinenko V, Ratov A., Lazorenko $\mathrm{S}$. The level of physical condition of students of various faculties of the pedagogical university. International Journal of Applied Exercise Physiology. 2019; 8 (3): 153-158. https://doi.org/10.26655/IJAEP.2019.9.19

17.de la Vega R, Jimenez-Castuera R, Leyton-Roman M. Impact of Weekly Physical Activity on Stress Response: An Experimental Study. Frontiers in Psychology. 2021;11. https://doi.org/10.3389/fpsyg.2020.608217

18.Rundle AG, Chen Y, Quinn JW, Rahai N, Bartley K, Mooney SJ, et al. Development of a Neighborhood Walkability Index for Studying Neighborhood Physical Activity Contexts in Communities across the US over the Past Three Decades. Journal of Urban Health-Bulletin of the New York Academy of Medicine. 2019;96(4):583-590. https://doi.org/10.1007/s11524-019-00370-4

19.Sáez I, Solabarrieta J, Rubio I. Motivation for Physical Activity in University Students and Its Relation with Gender, Amount of Activities, and Sport Satisfaction. Sustainability 2021;13:3183. https://doi.org/10.3390/su13063183

20.Shoesmith A, Hall A, Hope K, Sutherland R, Hodder RK, Trost SG, et al. Associations between in-school-hours physical activity and child health-related quality of life: A cross-sectional study in a sample of Australian primary school children. Preventive Medicine Reports. 2020;20. https://doi.org/10.1016/j.pmedr.2020.101179

21.Fraile-Garcia J, Tejero-Gonzalez CM, Esteban-Cornejo I, Veiga OL. Association between enjoyment, motor selfefficacy, physical activity and academic performance in physical education. Retos-Nuevas Tendencias En Educacion Fisica Deporte Y Recreacion. 2019(36):58-63. https://doi.org/10.47197/retos.v36i36.63035

22.Gu XL, Chen YL, JacksonAW,Zhang T. Impact of a pedometerbased goal-setting intervention onchildren's motivation, motor competence, and physical activity in physical education. Physical Education and Sport Pedagogy. 2018;23(1):54-65. https://doi.org/10.1080/17408989.2017.1341475

23.Yli-Piipari S, Grasten A, Huhtiniemi M, Salin K, Seppala S, Hakonen H, et al. Predictive Strength of Physical Education-Centered Physical Literacy Indicators on Physical Activity. Journal of Teaching in Physical Education. 2021;40(2):303-311. https://doi.org/10.1123/jtpe.2019-0144

24.Kuzmina OI, Lebedinsky VYu, Shvachun OA. Modern technologies of pedagogical influence and new types of physical activity in health preservation of student youth. Theory and Practice of Physical Culture. 2020; 1: 14-16.

25.Lubysheva LI. Physical and sports culture: content, relationships and dissociation. Theory and Practice of Physical Culture. 2002; 3: 11-14.

26.Abrashina IV. Russian folk outdoor games as a means of developing moral behavior in the learning process [Cand. Diss]. St. Petersburg; 2005. (In Russian).

27.Voldina TV. Game as an element of traditional culture of the $\mathrm{Ob}$ Ugrians (outdoor games with pebbles and sticks: comparative analysis). Vestnik UgrovedeniyaBulletin of Ugric Studies. 2018;8(3):503-524. https://doi.org/10.30624/2220-4156-2018-8-3-503-524

28. Gzhemskaya NKh. Pedagogical conditions for the realization of social functions of physical culture based on the use of outdoor games [Cand. Diss]. Naberezhnye Chelny; 2006. (In Russian).
29.Azizbaev SS. Historical information on the development of Kyrgyz traditional games and competitions. Tomsk Journal of Linguistics and Anthropology. 2020(2):97-105. https://doi.org/10.23951/2307-6119-2020-2-97-105

30.Nizhnikh IK. Formation of the foundations of legal culture in senior adolescents of the risk group by means of play activities [Cand. Diss]. Moscow; 2014. (In Russian).

31.Bochaver AA, Korzun AN, Polivanova KN. Outdoor Pastimes of Children and Teenagers. Psychology The Journal of the Higher School of Economics. 2017;14(3):470-490.

32.Zayachuk TV. Formation of creative abilities of students of pedagogical universities means of choreography and movement games. Uchenye zapiski universiteta imeni PF Lesgafta 2007. (In Russian). https://doi.org/10.5930/issn.1994-4683.2007.06.28.p31-3

33. Morgachev OV, Khramtsov PI. Hygienic characteristics of a physically active lifestyle of primary school children of different gender. Population Health and Life Environment. 2020(8):26-30. https://doi.org/10.35627/2219-5238/2020-329-8-26-30

34.Zulkarnayev TR, Agafonov A, Kazak AA, Khisamiev II, Povargo EA, Zulkarnaeva AT. Hygienic assessment of hemodynamic parameters of schoolchildren and students with different motor activity level. Population Health and Life Environment. 2019(2):19-25.

35.Bauer OP. Outdoor and sports games in the professional training of specialists in physical culture of preschoolers [Cand. Diss]. St. Petersburg; 2005. (In Russian).

36.Akaneeva EA. The Influence of Physical Education With the Use of Karate on the Physical Development of Children Aged 6 to 7. Tomsk State University Journal. 2020(455):152-156. https://doi.org/10.17223/15617793/455/21

37.Golubeva VV. Outdoor games in the system of training coaches for cyclic sports [Cand. Diss]. Moscow; 1997. (In Russian).

38.Kovaleva MV. The method of using mobile and elements of sports games in the classroom with students of special medical groups with disabilities of the cardiovascular system [Cand. Diss]. Shuya; 2012. (In Russian).

39. Ovsyannikova IN. The content and organization of physical education of university students based on the use of beach handball means [Cand. Diss]. Krasnodar; 2008. (In Russian).

40.Tomilin KG, Ovsyannikova IN. Game types of recreation at spa resorts [Internet]. Saratov: IPR Media; 2019. [updated 2021 Jun 15; cited 2021 May 5]. (In Russian). Available from: http://www.iprbookshop.ru/83823.html

41.Jones GJ, Carlton T, Hyun M, Kanters M, Bocarro J. Assessing the contribution of informal sport to leisure-time physical activity: a new perspective on social innovation. Managing Sport \& Leisure. 2020; 25(3): 161-174. https://doi.org/10.1080/23750472.2019.1620627

42.Milanović Z, Pantelić S, Čović N, Sporiš G, Mohr M, Krustrup P. Broad-spectrum physical fitness benefits of recreational football: a systematic review and metaanalysis. $B r \quad J$ Sports Med. 2019; 53(15): 926-939. https://doi.org/10.1136/bjsports-2017-097885

43.Hartman CL, Barcelona RJ, Trauntvein NE, Hall SL. Well-being and leisure-time physical activity psychosocial factors predict physical activity among university students. Leisure Studies. 2020;39(1):156-164. https://doi.org/10.1080/02614367.2019.1670722

44.Zheleznov NN, Ponomarev VV, Levitskaya AN, Zheleznova EN. Fitness football in physical education of female students of the university. Physical Culture: Upbringing, Education, Training. 2021; 1: 25-27. 
45.Ovsyannikova IN, Tomilin KG, Vasilkovskaya YuA, Laktionova EG, Malygina LV. «Game method» in the classroom of elective disciplines in physical culture and sports. Scientific Notes of the P.F. Lesgaft. 2020; 11(189): 378-384.

46.Tomilin KG, Mikhailova TV, Kuznetsova MM. Sailing: $A$ Yearly Training Cycle for Qualified Riders: A Study Guide. St. Petersburg: Lan; 2020. (In Russian).

47.Tomilin KG. Management of recreational activities at spa resorts. Saratov: IPR Media; 2019. (In Russian).

48.Ovsyannikova IN. Signs, components and classifications of play types of recreation. Bulletin of the Sochi State University of Tourism and Resort Business. 2011. 2(16). 159-161. (In Russian).

49.Di Battista R, Robazza C, Ruiz MC, Bertollo M, Vitali F, Bortoli L. The student's intention to engage in physical activity in their free time: the interaction of the climate associated with tasks, satisfaction of competence needs and psychobiosocial states in physical education. European Physical Education Review. 2019; 25(3): 761-777. https://doi.org/10.1177/1356336X18770665

50.Dao Chan Tuk. The effect of physical activity on the biological age parameters of women from 17 to 18 years old. Journal of Sports Medicine and Therapy. 2018; 3: 75-79. https://doi.org/10.29328/journal.jsmt.1001030

51.Tomilin KG. Motivation and interests of Sochi youth involved in physical culture and sports. In: 2nd All-Russian Scientific and Practical Conference "Physical Education and Student Sports through the Eyes of Students», Kazan, November 2427, 2016, Kazan; 2016. P. 226-229. (In Russian).

52.Tomilin KG. Optimization of physical culture lessons based on studying the interests of students. In: All-Russian scientific-practical conference "Motor activity. Sport. Personality». Yoshkar-Ola, December 13-14, 2018, YoshkarOla, 2019. P. 105-108. (In Russian).

\section{Information about the authors:}

Inna N. Ovsyannikova; Candidate of Pedagogical Sciences, Associate Professor; https://orcid.org/0000-0001-8011-9420; ovsinhandball@mail.ru; Sochi State University; Sochi, Russia.

Konstantin G. Tomilin; (Corresponding Author); candidate of pedagogical sciences, associate professor; https://orcid. org/0000-0002-9496-696X; tomilin-47@bk.ru; Sochi State University, Sochi, Russia.

Yulia A. Tumasyan; Candidate of Pedagogical Sciences, Associate Professor; https://orcid.org/0000-0002-9477-7202; butterfly72@mail.ru; Sochi State University; Sochi, Russia.

Yulia A. Vasilkovskaya; Candidate of Pedagogical Sciences, Associate Professor; https://orcid.org/0000-0001-8264-4157; ua2005@bk.ru; Sochi State University; Sochi, Russia.

Lyudmila V. Malygina; Candidate of Pedagogical Sciences, Associate Professor; https://orcid.org/0000-0003-2388-2547; Imalygina@mail.ru; Sochi State University; Sochi, Russia.

Cite this article as:

Ovsyannikova IN, Tomilin KG, Tumasyan YA, Vasilkovskaya YA, Malygina LV. Game method to increase students' motivation to engage in elective disciplines in physical culture and sports. Physical Education of Students, 2021;25(3):197-204. https://doi.org/10.15561/20755279.2021.0308

This is an Open Access article distributed under the terms of the Creative Commons Attribution License, which permits unrestricted use, distribution, and reproduction in any medium, provided the original work is properly cited http://creativecommons.org/licenses/by/4.0/deed.en

Received: 12.05.2021

Accepted: 23.06.2021; Published: 30.06.2021 